\title{
Comparative Study of Soil Nutrient Status in Three Forest Types of Dharmapuri Forest Circle, Tamil Nadu, South India
}

\author{
K.S. Dhinesh ${ }^{1}$, S. Radhakrishnan ${ }^{2}$, A. Balasubramanian ${ }^{2}$ and K. Sivakumar ${ }^{3}$ \\ ${ }^{1}$ Department of Horticulture, PGP College of Agriculture Sciences, Namakkal, \\ Tamil Nadu, India \\ ${ }^{2}$ Department of Silviculture, ${ }^{3}$ Department of Agroforestry, Forest College and Research \\ Institute, Mettupalayam, Tamil Nadu, India
}

*Corresponding author

\section{Keywords}

Soil nutrient, Forest types, Dry deciduous forest, Nitrogen, Phosphorous and potassium

Article Info

Accepted:

12 January 2019

Available Online:

10 February 2019

\section{A B S T R A C T}

A study was carried out to investigate the comparative study of soil nutrient status such as soil chemical properties in different forest types of Dharmapuri forest circle of Tamil Nadu. Totally forty soil samples were collected from three forest types viz., Tropical dry deciduous forest, Tropical dry evergreen forest and Tropical dry thorn forest. The results revealed that nitrogen content was exhibited high $\left(334 \mathrm{kgha}^{-1}\right)$ in Tropical dry deciduous forest due to a large extent on the amount and properties of organic matter in the forest floor for Nitrogen rich upper layers as compared to the lower layers. Available phosphorous content was recorded higher $\left(24.99 \mathrm{kgha}^{-1}\right)$ in soil of Tropical dry deciduous forest because phosphorus is the ore based mineral which has no influence by plant communities in that area and this might be the reason for higher phosphorus content forest soils. Similarly, tropical dry deciduous forest exhibited higher potassium content (226.37 $\mathrm{kgha}^{-1}$ ) which may be attributed to the fact that most of the dry deciduous forest soils are rich in potassium due to presence of potassium containing minerals.

\section{Introduction}

Indian forests are very diverse based on the rainfall, soil, topography and climatic factors. The interaction between forest vegetation and site factors decides the type, pattern and distribution across ecozones. Variable temperature and moisture differences generated from elevation and aspect gradients may have some effect on organic matter decomposition (Griffiths et al., 2009). The soil and vegetation have a complex interrelation since they develop together over a long period of time. The presence of essential soil nutrients will provides the best information towards nutrient cycling and biochemical cycle in the soil plant ecosystem (Gairola et al., 2012). An adequate knowledge of various forest soils and the complex relationship between the life of various trees and other plants of the forest is highly essential to understand the soil plant relationship. 
Soil is a complex system where in living soil organisms belonging to different taxonomic groups interact at different levels within the community and plays a significant role in maintenance of soil properties (Garbeva et al., 2004). Forest soils are enriched with enormous nutrients due to the decomposition processes of the plants litter. So the soils in mountainous region are very well suited for the high productivity and sustainability. Altitude is often employed to study the effects of climatic variables on soil nutrient content and organic matter dynamics (Lemenih and Itanna, 2004). The change in forest types influences soil organic matter by controlling soil water balance, soil erosion, geologic deposition processes, species and biomass production of the native vegetation and cultivated plants (Tan et al., 2004). Change in other soil properties have been found to be more variable, perhaps due to differences in climate, crop rotation, soil type or length of time and soil has been under organic management (Lockeretz et al., 1981).

\section{Materials and Methods}

\section{Geographical details of study area}

The forest areas in Dharmapuri circle have very rich diversity of flora including many endangered species of flora and fauna. Dharmapuri forest circle lies between $11^{\circ} 53^{\prime}$ $\mathrm{N}$ to $12^{\circ} 02^{\prime} \mathrm{N}$ and $77^{\circ} 40^{\prime} \mathrm{E}$ to $78^{\circ} 17^{\prime} \mathrm{E}$. The circle shares inter-state boundary with the adjoining states of Karnataka and Andhra Pradesh. This area harbors various types of forests along with mammals, reptiles, birds and several micro-organisms.

The extent of forest area in Dharmapuri district is 4497.77 sq.km with the forest cover of 1660.4 sq.km while in Krishnagiri district the forest area is 4143.00 sq. $\mathrm{km}$ with the forest cover 1489.27 sq.km.
The forest areas in Dharmapuri circle with three forest divisions namely Dharmapuri, Harur and Hosur Forest Division have very rich diversity of flora including many endangered species of flora and fauna. It is located in the Western Ghats and includes 2 of the 10 bio geographic provinces of India. The Cauvery River flows through Hosur and Dharmapuri divisions to a length of $50 \mathrm{~km}$ with waterfalls at Hogenakkal as an international tourist's attraction.

\section{Experimental site}

In Dharmapuri forest circle 40 sample plots of size 0.1 ha each were laid based on the forest types available at forest range level. The sample plots were laid based on stratified random sampling method at range level with a sampling intensity of 0.001 per cent. Among 40 sample plots laid, 34 in tropical dry deciduous forest, 2 in tropical dry evergreen forests and 6 in tropical thorn forest covering the forest area in Dharmapuri forest circle.

\section{Different forest types in Dharmapuri forest circle}

The largest area of the Dharmapuri forest land is occupied by dry deciduous forests. The dry season is long and most of the trees remain leafless during that season. The forest trees are not dense, 10 to $15 \mathrm{~m}$ in height, and undergrowth is abundant. The forests are dominated by Azadirachta indica, Dalbergia paniculata, Albizia amara, Terminalia arjuna, Anogeissus latifolia, Chloroxylon swietenia, Hardwickia binata, Zizyphus glabrata, Wrightia tinctoria, Dendrocalamus strictus.

\section{Dry deciduous forests}

Dry deciduous forests occur in the leeward (eastern slope) side of the Western Ghats at an elevation of 300-900 m msl. These forests are characterized by the predominance of 
hardwood tree species. The canopy cover is less and normally does not exceed $25 \mathrm{~m}$. The most common trees in this forest pattern are sal, acacia and bamboo. These forests are highly variable due to anthropogenic activities like fire and grazing. The rainfall pattern of the forest ranges from 1000 to $1500 \mathrm{~mm}$. The most common trees found in this forest type were satinwood, Bitter albizia and East Indian ebony (Fig. 1).

\section{Dry evergreen forest}

In general, these forests occur on the windward side (western slopes) of the Western Ghats in at an altitude of 200-1500 m (above $\mathrm{msl}$ ) and it receives $2500-5000 \mathrm{~mm}$ rainfall. More than $50 \%$ of the tree species in these forests are highly endemic. Most of the evergreen trees have tall hardwoods with broadleaves. They grow very close to each other and the canopy cover is very thick, and always looks green. In this forest system, the trees are composed of three distinct layers, the shrubs covers the ground surface followed by short structured trees and then tall trees. Various varieties of orchids and ferns are present in the trunk of tress. Due to dense foliage the light that reaches the under story is very less. The common trees found were Memecylon, Sawser berryand Ceylon boxwood tree (Fig. 1).

\section{Dry thorn forest}

This forest type is confined to the eastern part of Dharmapuri, with mean annual rainfall of $850 \mathrm{~mm}$ (range: $450-1,230 \mathrm{~mm}$ ) and a fourmonth dry season (rainfall less than $50 \mathrm{~mm}$ per month).Most of the species in this forest types are exhibited with thorny species not only the trees but also the shrubs and herbs. Those thorny species exceeds upto the height of $20 \mathrm{~m}$. Tree species dominated in this forest type are White babool, Umbrella tree and Bastard teak (Fig. 1).

\section{Collection of soil samples}

Representative soil samples were collected from the selected sample plots based on forest types available at range level. The soil samples were collected at a depth of 0-15 cm (surface) and $15-30 \mathrm{~cm}$ (sub surface) by following the standard soil sampling procedure (Fig. 2). During collection of samples; dead plants, furrow, old manures, wet spots, areas near trees and compost pits were excluded. This was done to minimize differences, which may arise because of the dilution of soil organic matter by other external factors.

Totally forty soil samples collected from 40 sample plots of Dharmapuri forest circle were air dried, mixed well and passed through a 2 $\mathrm{mm}$ sieve for the analysis of selected soil properties. The soil chemical properties were analyzed by following standard procedure as listed in table 1.

\section{Soil analysis}

\section{Available nitrogen}

The amount of soil available nitrogen in soil sample was determined by alkaline permanganate method (Subbiah and Asija, 1956) (Table 1).

\section{Available phosphorous}

The amount of available phosphorus from soil was extracted with Bray I extractant $(0.025 \mathrm{~N}$ $\mathrm{HCl}+0.03 \mathrm{~N} \mathrm{NH4F)} \mathrm{Blue} \mathrm{colour} \mathrm{was}$ developed using ascorbic acid as reductant and the colour intensity measured at $660 \mathrm{~nm}$ with photoelectric colorimeter (Bray and Kurtz, 1945) (Table 1).

\section{Available potassium}

Neutral normal ammonium acetate (N $\mathrm{NH}_{4} \mathrm{OAc}$ ) was used to extract the available 
potassium in the soil. The soil available potassium concentration was read in flame photometer (Stanford and English, 1949) (Table 1).

\section{Statistical analysis}

Soil samples collected at different altitudes in dry deciduous forest were analyzed. The experimental data were subjected to statistical analysis to determine the treatment effect and other factors (Panse and Sukhatme, 1985) and computer compilation was done using AGRESS.

\section{Results and Discussion}

Forest types are one of the main factors which directly or indirectly affect the soil characteristics. The altitude determines the micro-climate of a site. The present study projects the nutrient status of soil properties with respect to different forest types of Dharmapuri forest circle (Table 2)

\section{Available nitrogen}

The available nitrogen content of the soil samples of Dharmapuri Forest Circle ranged from $217.2 \mathrm{~kg} \mathrm{ha}^{-1}$ to $342.6 \mathrm{~kg} \mathrm{ha}^{-1}$ (Table 2). The surface and sub surface soil samples of
Tropical dry deciduous forest registered high available nitrogen $(342.6 \mathrm{~kg}$ ha-1and $325.4 \mathrm{~kg}$ ha-1) and low value both surface and sub surface soils of Tropical thorn forest (238.4 $\mathrm{kg} \mathrm{ha}^{-1}$ and $217.2 \mathrm{~kg} \mathrm{ha}^{-1}$ ) (Table 2).

The mean values of available nitrogen of soil samples were high in Tropical dry deciduous forest $\left(334.0 \mathrm{~kg} \mathrm{ha}^{-1}\right)$, followed by Tropical dry evergreen forest $\left(273.7 \mathrm{~kg} \mathrm{ha}^{-1}\right)$ and low in soils of Tropical thorn forest $(227.8 \mathrm{~kg}$ ha $^{-1}$ ) (Table 2).

\section{Available Phosphorus}

The available phosphorus content of the soil samples collected from Dharmapuri Forest Circle ranged from $17.76 \mathrm{~kg} \mathrm{ha}^{-1}$ to $26.12 \mathrm{~kg}$ $\mathrm{ha}^{-1}$ (Table 2). The maximum value was recorded in both surface and sub surface soils of Tropical dry deciduous forest $(26.12 \mathrm{~kg}$ $\mathrm{ha}^{-1}$ and $23.86 \mathrm{~kg} \mathrm{ha}^{-1}$ ) and the minimum $\left(21.51 \mathrm{~kg} \mathrm{ha}^{-1}\right.$ and $19.75 \mathrm{~kg} \mathrm{ha}^{-1}$ ) in Tropical dry evergreen forest soils at surface and sub surface layers. There exists a significant difference among the available phosphorus content in forest type studied. The surface soil registered higher value for available phosphorus than sub surface soil in all the three forest types studied.

Table.1 Standard analytical procedures followed for soil analysis

\begin{tabular}{|c|l|l|l|}
\hline $\begin{array}{c}\text { Sl. } \\
\text { No. }\end{array}$ & \multicolumn{2}{|c|}{ Estimation } & \multicolumn{2}{|c|}{ Method } & \multicolumn{1}{|c|}{ Author } \\
\hline A. & \multicolumn{2}{|c|}{ Chemical properties } & \multicolumn{2}{|c|}{$\begin{array}{l}\text { Subbiah and } \\
\text { Asija (1956) }\end{array}$} \\
\hline $\mathbf{1 .}$ & Available nitrogen & $\begin{array}{l}\text { Alkaline } \\
\text { permanganate } \\
\text { method }\end{array}$ & $\begin{array}{l}\text { Bray and Kurtz } \\
\text { (1945) }\end{array}$ \\
\hline $\mathbf{2 .}$ & Available phosphorus & Bray1 method & $\begin{array}{l}\text { Stanford and } \\
\text { English (1949) }\end{array}$ \\
\hline 3. & Available potassium & $\begin{array}{l}\text { Neutral normal } \\
\mathrm{NH}_{4} \mathrm{OAc}, \text { using } \\
\text { nlame photometry }\end{array}$ & Flame \\
\hline
\end{tabular}


Table.2 Soil chemical properties of Dharmapuri forest circle

\begin{tabular}{|c|c|c|c|c|c|c|c|c|c|c|}
\hline \multirow{2}{*}{ S.No. } & \multirow{2}{*}{ Forest type } & \multicolumn{3}{|c|}{ Available Nitrogen $\left(\mathrm{kgha}^{-1}\right)$} & \multicolumn{3}{|c|}{ Available Phosphorus (kgha-1) } & \multicolumn{3}{|c|}{ Available Potassium (kgha $\left.{ }^{-1}\right)$} \\
\hline & & $\begin{array}{c}\text { Surface }(0- \\
15 \mathrm{~cm})\end{array}$ & $\begin{array}{l}\text { Subsurface } \\
(15-30 \mathrm{~cm})\end{array}$ & Mean & $\begin{array}{r}\text { Surface } \\
(0-15 \mathrm{~cm})\end{array}$ & $\begin{array}{l}\text { Subsurface } \\
(15-30 \mathrm{~cm})\end{array}$ & Mean & $\begin{array}{l}\text { Surface }(0- \\
15 \mathrm{~cm})\end{array}$ & $\begin{array}{l}\text { Subsurface } \\
(15-30 \mathrm{~cm})\end{array}$ & Mean \\
\hline 1 & $\begin{array}{c}\text { Tropical dry } \\
\text { deciduous forest }\end{array}$ & 342.6 & 325.4 & 334.0 & 26.12 & 23.86 & 24.99 & 238.91 & 213.82 & 226.37 \\
\hline 2 & $\begin{array}{c}\text { Tropical dry } \\
\text { evergreen forest }\end{array}$ & 281.6 & 265.8 & 273.7 & 21.51 & 19.75 & 20.63 & 152.08 & 134.21 & 143.15 \\
\hline 3 & $\begin{array}{c}\text { Tropical thorn } \\
\text { forest }\end{array}$ & 238.4 & 217.2 & 227.8 & 17.76 & 23.62 & 20.69 & 138.63 & 109.38 & 124.00 \\
\hline $\begin{array}{l}\text { Mean } 2 \\
\text { CV \% }\end{array}$ & $\begin{array}{ccc}287.53 & 269.47 & 21.80 \\
3.59 & 5.90 & 4.68\end{array}$ & $\begin{array}{cc}22.41 & 176.54 \\
3.32 & 4.57\end{array}$ & $\begin{array}{l}152.47 \\
5.63\end{array}$ & & & & & & & \\
\hline
\end{tabular}

Chart.1 Soil chemical properties in different forest types of Dharmapuri forest circle

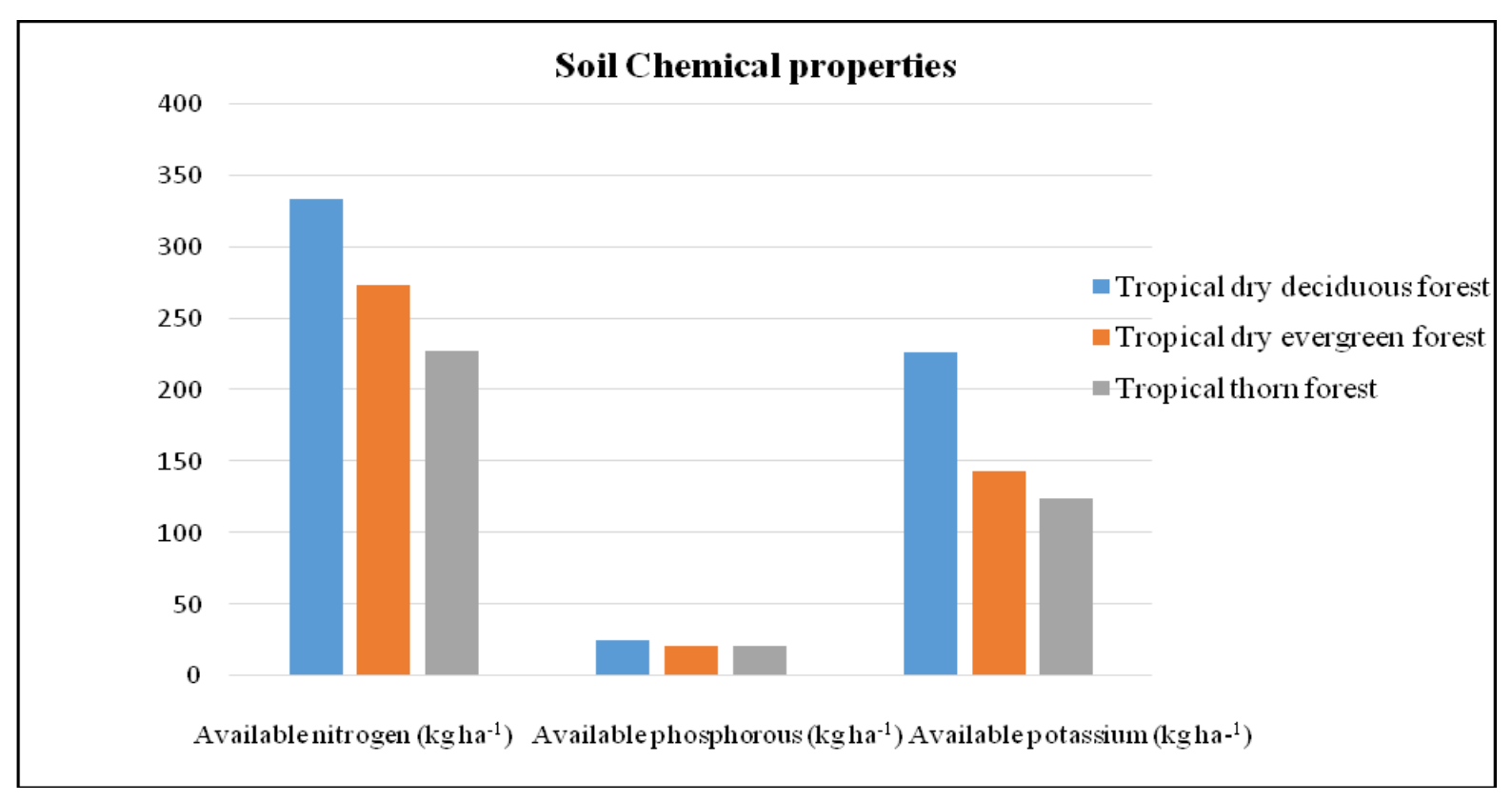


Fig.1 Field view of different forest types in Dharmapuri forest circle Tropical dry deciduous forest Tropical dry evergreen forest
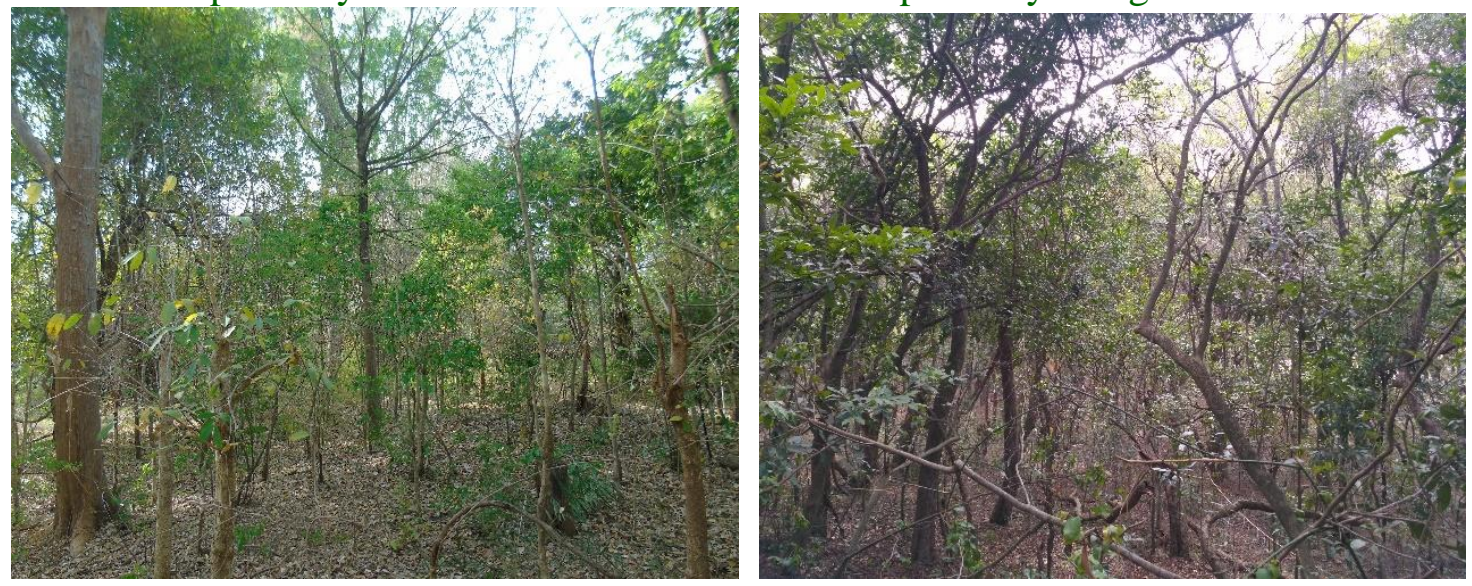

Tropical dry thorn forest

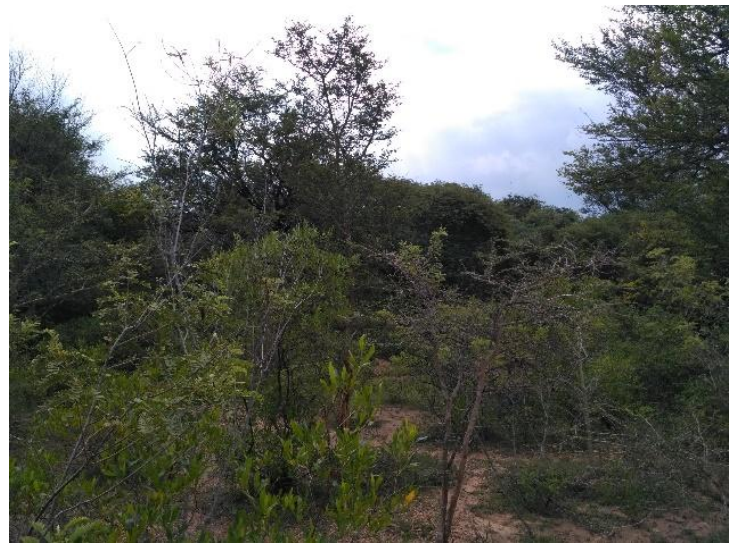

Fig.2 Collection of soil samples

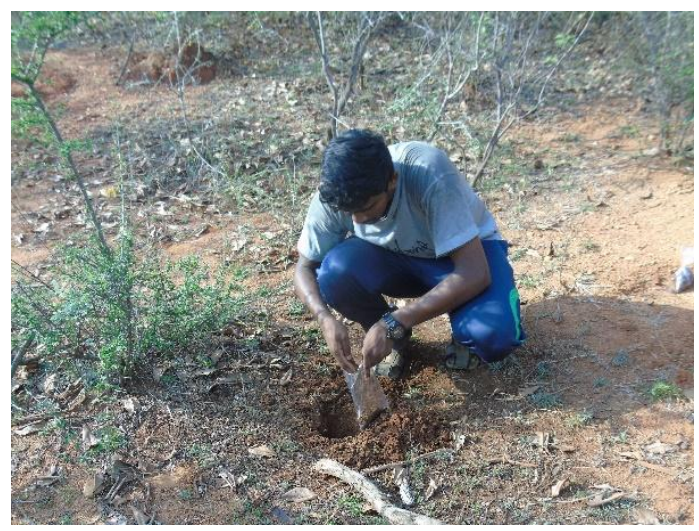

Among the mean values of available collected, Tropical dry deciduous forest soil phosphorus content of the soil samples registered higher value (24.99 kg ha $\left.{ }^{-1}\right)$ 
followed by soil in Tropical thorn forest $\left(20.69 \mathrm{~kg} \mathrm{ha}^{-1}\right)$. Lower value $\left(20.63 \mathrm{~kg} \mathrm{ha}^{-1}\right)$ of available phosphorus was recorded in Tropical dry evergreen forest among the forest types studied (Table 2).

\section{Available potassium}

The available potassium content in surface and subsurface soil layers of forests in Dharmapuri Forest Circle ranged from 109.38 $\mathrm{kg} \mathrm{ha}^{-1}$ to $238.91 \mathrm{~kg} \mathrm{ha}^{-1}$ (Table 2). Soil samples of Tropical dry deciduous forest showed highest value of available potassium in both surface and sub surface layers (238.91 $\mathrm{kg} \mathrm{ha}{ }^{-1}$ and $213.82 \mathrm{~kg} \mathrm{ha}^{-1}$ ) and it is significantly different when compared to soils of Tropical dry evergreen and Tropical thorn forest. In Tropical thorn forest, both surface and sub surface soil samples recorded the lowest value of available potassium (138.63 $\mathrm{kg} \mathrm{ha}^{-1}$ and $109.38 \mathrm{~kg} \mathrm{ha}^{-1}$ ). There was a significant decrease in available potassium with increase in depth of soil in all the three forest types evaluated.

The mean values revealed that, the soils of Tropical dry deciduous forest $\left(226.37 \mathrm{~kg} \mathrm{ha}^{-1}\right)$ recorded significantly higher value for available potassium content followed by Tropical dry evergreen forest $(143.15 \mathrm{~kg}$ $\mathrm{ha}^{-1}$ ). Low value for available potassium content was registered in Tropical thorn forest (124.00 $\mathrm{kg} \mathrm{ha}^{-1}$ ) (Table 2).

\section{Available nitrogen}

The soil available nitrogen content ranged from 227.8 to $334.0 \mathrm{~kg} \mathrm{ha}^{-1}$ in soil samples collected in Dharmapuri Forest Circle. High value of nitrogen (334.0 kg ha $\left.{ }^{-1}\right)$ was observed in Tropical dry deciduous forest soil (Chart 1). Regular addition of plant residues in soil and decomposition, might be the reason for the higher nitrogen content in forest soil. The results confirms the earlier findings for high soil nitrogen in shola forest of Nilgiri hills, Tamil Nadu (Sonaimuthu, 2016; Venkatachalam and Kalaiselvi, 2007).

The higher value of available nitrogen in the surface layer could be attributed to higher water holding capacity and the presence of heavy litter and humus contents in the forest floor. The availability of Nitrogen depends to a large extent on the amount and properties of organic matter (De Hann, 2007). Therefore the high amount of organic matter inthe forest floor may be the reason for Nitrogen rich upper layers as compared to the lower layers.

\section{Available phosphorous}

The available phosphorus content of the soil samples collected from three forest types in Dharmapuri Forest Circle ranged from 20.63 $\mathrm{kg} \mathrm{ha}^{-1}$ to $24.99 \mathrm{~kg} \mathrm{ha}^{-1}$. Among the mean values of available phosphorus content, the soils of Tropical dry deciduous forest recorded higher value $\left(24.99 \mathrm{~kg} \mathrm{ha}^{-1}\right)($ Chart $1)$.

The phosphorus is the ore based mineral which has no influence by plant communities in that area and this might be the reason for higher phosphorus content forest soils. Such high values of available phosphorous in soils of shola forest were reported by Mani et al., 2006 and moist deciduous forest in Western Ghats (Bhuvanesh, 2017).

The top soil has higher available phosphorus content and decreases with increase in soil depth. The results are in accordance with the findings of high available in sholas and moist deciduous forest (Mani et al., 2006). With increasing depth, there was a great reduction in soil available phosphorus in all locations.

\section{Available potassium}

The available potassium content in forest soils of Dharmapuri Forest Circle ranged from124.00 kg ha ${ }^{-1}$ to $226.37 \mathrm{~kg} \mathrm{ha}^{-1}$. 
Tropical dry deciduous forest soil recorded high mean value of $226.37 \mathrm{~kg} \mathrm{ha}^{-1}$ (Chart 1). However, the soil available potassium in parts of Nilgiri hills, Tamil Nadu, varied considerably (Venkatachalam and Kalaiselvi, 2007).

The higher values of available potassium in the soil may be attributed to the fact that most of the Indian soils are rich in potassium (Naidu et al., 2011), due to presence ofpotassium containing minerals like illite, muscovite, gluconite, biotite, phlogopite, sanidine and orthoclase in Indian soil (Sekhon, 1999).

In conclusion, the comparison of soil properties in three forest types of Dharmapuri Forest Circle revealed that Tropical dry deciduous forest soil exhibited high values for chemical properties like Available Nitrogen, Available Phosphorous and Available Potassium. Whereas low values were recorded for chemical properties from soil of Tropical thorn forest.

\section{Acknowledgement}

The authors acknowledge the support of Tamil Nadu Forest Department for funding the research project on "Inventory of medicinal plants diversity in Salem and Dharmapuri Forest Circles of Tamil Nadu". Special thanks to Dean, Forest College and Research Institute, Mettupalayam for providing technical support.

\section{References}

Bhuvanesh, P. (2017). Study on vegetation analysis in Thalamalai range of Sathyamanagalam Tiger Reserve. (M.Sc. Thesis), Forest College and Research Institute, Tamil Nadu Agricultural University, Mettupalayam.

Bray, R. H., and Kurtz, L. (1945).
Determination of total, organic, and available forms of phosphorus in soils. Soil science, 59(1), 39-46.

De Hann, S. (2007). Humus, its formation, its relation with the mineral part of the soil and its significance for soil productivity -Organic matter studies. International Atomic Energy Agency, 1, 21-30.

Gairola, S., M. Sharma, C., Ghildiyal, S. K., and Suyal, S. (2012). Chemical properties of soils in relation to forest composition in moist temperate valley slopes of Garhwal Himalaya, India (Vol. 32)

Garbeva P., Van Veen J.A. and VanElsas J.D. (2004); Microbial diversity insoil: selection microbial populations by plant and soil type and implications for disease suppressiveness. Annual review of phytopathology, 42:243-270.

Griffiths, R. P., Madritch, M.D., Swanson, A.K. (2009). The effects of topography on forest soil characteristics in the Oregon Cascade Mountains (USA): Implications for the effects of climate change on soil properties. Forest Ecology and Management, 257, 1-7

Lemenih M, and F. Itanna, "Soil Carbon Stocks and Turnovers in Various Vegetation Type and Arable Lands along an Elevation Gradient in Southern Ethiopia," Geoderma, Vol. 123, No. 12, 2004, pp. 177-188

Lockeretz, W, G. Sheares and D.H. Kohl. Organic farming in the corn belt, Science (Washington DC) 211: 540547. 1981

Mani, A. K., Manivasakan.S. and R., S. (2006). Impact of forest types on soil properties. Paper presented at the International Forestry and Environment Symposium. Forest College and Research Institute, Tamil Nadu Agricultural University, India.

Naidu, L., Sidhu, G., Sarkar, D., and Ramamurthy, V. (2011). Emerging 
deficiency of potassium in soils and crops of India. Karnataka Journal of Agricultural Sciences, 24(1).

Panse, V., and Sukhatme, P. (1985). Statistical methods for Agricultural workers. ICAR. New Delhi. Paper presented at the Eyasu Mekonnen and Mintesinot Behailu (Eds.) Proceedings of the $3^{\text {rd }}$ Conference of the Ethiopian Society of Soil Science, Ethiopia.

Sekhon, G. (1999). Potassium in Indian soils and crops. Proceedings of Indian National Science Academy B, 65, 83108.

Sonaimuthu, M. S. (2016). Studies on Soil Quality Status as Influenced by Different Land Uses in Udhagai Range, Nilgiri South Forest Division, Tamil Nadu. (M.Sc.), Forest College and Research
Institute, Mettupalayam.

Stanford, G., and English, L. (1949). Use of the flame photometer in rapid soil tests for K and Ca. Agronomy Journal, 4l(9), 446-447.

Subbiah, B. V., Asija, G.L. (1956). A rapid method for estimation of available $\mathrm{N}$ in soil. Current Science, 25, 259-260.

Tan Z.X, R. Lal, N. E. Smeck and F. G. Calhoun, 2004. "Relationships between Surface Soil Organic Carbon Pool and Site Variables," Geoderma, Vol. 121, No. 3-4, pp. 185-187.

Venkatachalam, S., and Kalaiselvi, T. (2007). Neelakantan and S. Gunasekaran, "A Comparative Study on Soil Microflora and Nutrient Status of Sholas and Adjoining Vegetation," Indian Journal of Forestry, 30(2), 135-140.

\section{How to cite this article:}

Dhinesh, K.S., S. Radhakrishnan, A. Balasubramanian and Sivakumar, K. 2019. Comparative Study of Soil Nutrient Status in Three Forest Types of Dharmapuri Forest Circle, Tamil Nadu, South India. Int.J.Curr.Microbiol.App.Sci. 8(02): 1613-1621. doi: https://doi.org/10.20546/ijcmas.2019.802.189 